gives $93 \mathrm{~cm}$. instead of $63.5 \mathrm{~cm}$. obtained by Shumskiy and Zotikov. Using these new values, the annual bottom melt would be about $67 \mathrm{~cm}$.

It is interesting to note that if the density profile relative to the surface is invariant, making $d H / d h$ about 9 , then the bottom melting as calculated above would be about $113 \mathrm{~cm}$.

The remeasurements made at "Little America" station in 196r confirmed the order of annual change in elevation of the moving ice sheet: $63 \mathrm{~cm}$. decrease over a $4.2 \mathrm{yr}$. period or $15 \mathrm{~cm}$. $\mathrm{yr}^{-1}$, and the absolute velocity: $309 \mathrm{~m}$. $\mathrm{yr}^{-1}{ }^{-1}$. These two directly measured values strengthen the contention of ice shelf equilibrium and hence the deduced annual bottom melting of about $60 \mathrm{~cm}$. It is hoped that in the future added drill holes can be made for other vertical temperature profiles, particularly along the ice-shelf flow lines. It would be interesting also to have comparative regime figures for such ice shelves as Larsen, West or Amery where the higher annual temperatures should result in considerable difference in the strain values, net accumulation and perhaps in bottom melting. In the overall regime figures for Antarctica, as Shumskiy and Zotikov point out, the shelf bottom melting is an important factor, and more observations, indirect or direct, would be most helpful.

Office of Antarctic Programs,

A. P. Crary

National Science Foundation,

Washington 25, D.C., U.S.A.

Io September 1963

\title{
REFERENCES
}

Crary, A. P. 1961. Glaciological studies at Little America Station, Antarctica, 1957 and 1958. IGY Glaciological Report Series (New York, IGY World Data Center A, Glaciology, American Geographical Society), No. 5 .

Crary, A. P., and others. 1962. Glaciological studies of the Ross Ice Shelf, Antarctica, 1957-1960, by A. P. Crary, E. S. Robinson, H. F. Bennett and W. W. Boyd, Jr. IGY Glaciological Report Series (New York, IGY World Data Center A, Glaciology, American Geographical Society), No. 6.

Crary, A. P., and Chapman, W. H. 1963. Additional glaciological measurements at the abandoned Little America Station, Antarctica. Fournal of Geophysical Research, Vol. 68, No. 21, p. 6o64-65.

Shumskiy, P. A., and Zotikov, I. A. 1963 . On the bottom melting of the Antarctic ice shelves. Union Géodésique et Géophysique Internationale. Association Internationale d'Hydrologie Scientifique. Assemblée générale de Berkeley, 19-8-31-8 1963. Commission des Neiges et des Glaces, p. 225-31.

SIR,

\section{Long-term ice flow study}

This notice is submitted in order to place in a permanent, accessible form the record of an ice flow experiment whose completion is not expected until many years hence when the present generation of glaciologists will have passed away. Site of this experiment is the Blue Glacier on the northern flanks of Mt. Olympus, located on the Olympic Peninsula of western Washington State, U.S.A. (lat. $47^{\circ} 4^{8^{\prime}}$ N., long. $123^{\circ} 4^{\prime}$ W.).

On 9 -10 September 1963,32 markers were placed on the firn surface of the two Blue Glacier accumulation basins. Details of the marker construction and placement are shown in Figure I. Their locations are shown on the sketch map of the accumulation zone of Blue Glacier in Figure 2. The markers are numbered ${ }_{1}$ through $19(\mathrm{~s}=37 \mathrm{~cm}$.), and $2 \mathrm{I}$ through $33(\mathrm{~s}=56 \mathrm{~cm}$.). Marker No. 20

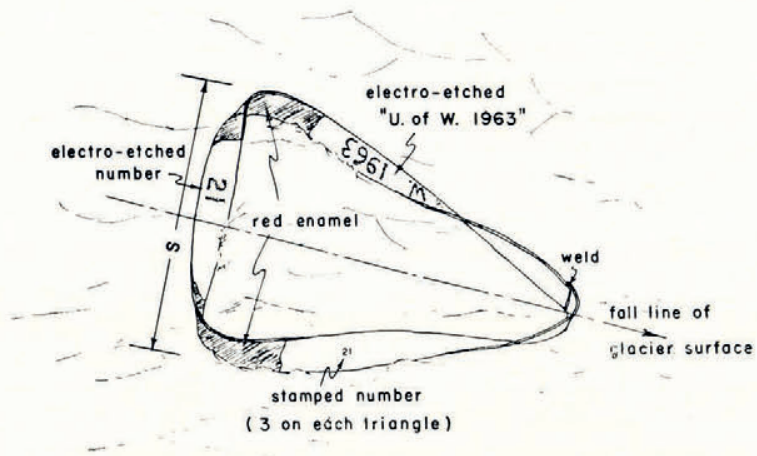

Fig. I. Blue Glacier long-term ice flow marker. See text for further details 


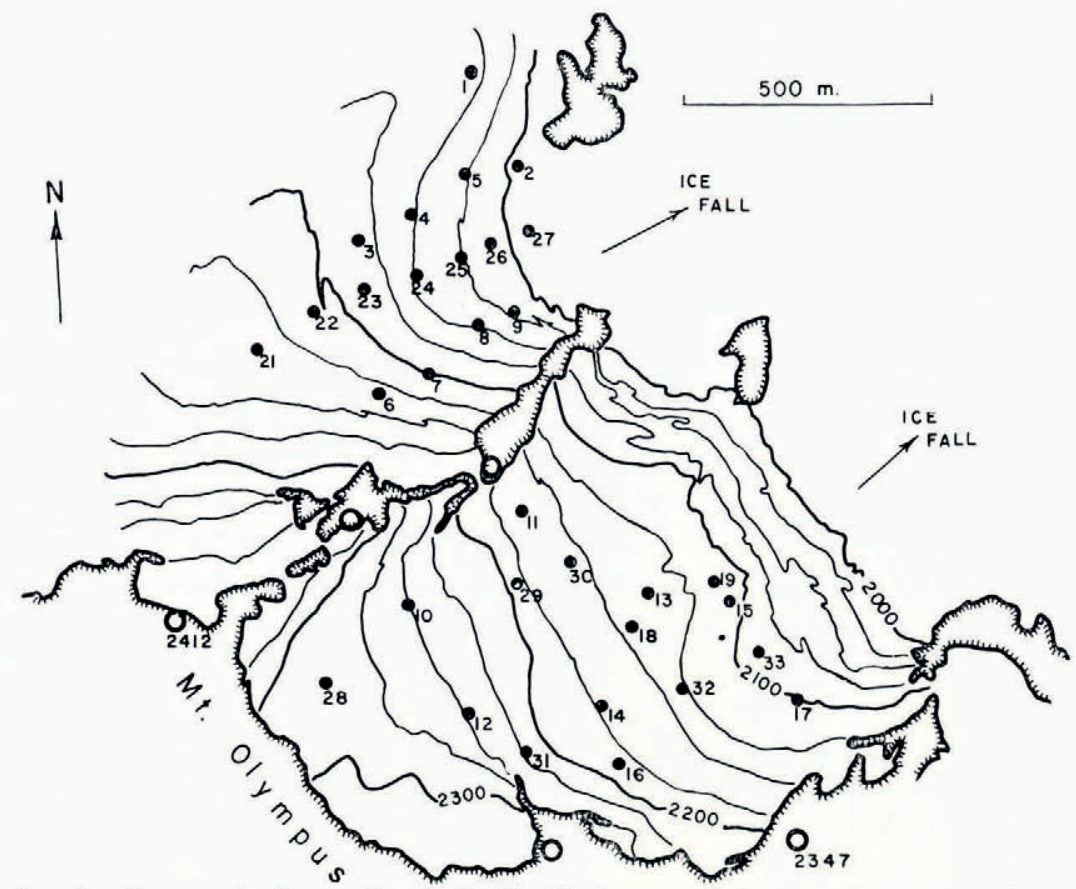

Fig. 2. Location of 32 long-term ice flow markers in the Blue Glacier accumulation zone. Contour interval is $25 \mathrm{~m}$. This topographic sketch map is derived from American Geographical Society Special Publication No. 34, "Nine glacier maps: northwestern North America", Sheet No. 2, Blue Glacier

( $\mathrm{s}=37 \mathrm{~cm}$.) has been placed in the Olympic National Park museum (U.S. National Park Service) in Port Angeles, Washington.

Marker construction material is stainless steel strip of cross-section $\left.50 \mathrm{~mm} . \times 2.8 \mathrm{~mm} .\left(2^{\prime \prime} \times \frac{1}{8}\right)^{\prime \prime}\right)$. Each strip is twisted $\mathrm{I}_{2} \frac{1}{2}$ times and the ends are joined to form an equilateral triangle. This configuration was chosen to provide maximum stability of position once incorporated in the ice, and as an unusual shape which would attract an observer's eye when the markers reappear.

The markers are all in a zone of heavy annual accumulation where they will rapidly become buried in firn, and eventually in glacier ice. Their reappearance on the lower part of the glacier years hence is expected to yield valuable information on flow lines and velocities deep in an active glacier. It is hoped that future glaciologists will be encouraged by this present notice to recover these markers and identify the flow lines.

Copies of this notice are being filed with the National Park Service and with the University of Washington archives, together with other pertinent data which include a topographic map showing the 1963 marker sites and the compass bearings from these sites to fixed reference points.

Department of Atmospheric Sciences,

E. LaChapelle

University of Washington,

Seattle 5 , Washington, U.S.A.

25 September 1963

SIR,

Glacial benches in south Victoria Land

In a recent letter McGregor ( 1963 ) questioned our interpretation of benches that occur at $\mathrm{I}, 200-$ $1,5 \mathrm{co} \mathrm{m}$. (and at other elevations) on the sides of the Wright and Victoria Valleys (Bull and others, 1962). We have interpreted the "benches" as having been carved by glaciers broader, shallower and higher than those which later cut the deeper U-form of the present valleys. However, McGregor considers that the benches are solely structural in origin and have been formed by differential erosion at the sandstone-dolerite, sandstone-basement or dolerite-basement contacts. 